\title{
Social Inequalities in Mobility During and Following the COVID-19 associated lockdown of the Madrid Metropolitan Area in Spain
}

\author{
Adrián Glodeanu ${ }^{1}$, Pedro Gullón ${ }^{2,3}$, Usama Bilal ${ }^{4,5}$ \\ ${ }^{1}$ PhD Student of Geography, Faculty of Geography and History, Universidad Complutense, Madrid, Spain \\ ${ }^{2}$ Public Health and Epidemiology Research Group, School of Medicine and Health Sciences, Universidad de Alcala, Alcala de \\ Henares, Madrid, Spain \\ ${ }^{3}$ School of Global, Urban and Social Studies, RMIT University, Melbourne, Australia \\ ${ }^{4}$ Urban Health Collaborative, Drexel Dornsife School of Public Health, Philadelphia, PA \\ ${ }^{5}$ Department of Epidemiology and Biostatistics, Drexel Dornsife School of Public Health, Philadelphia, PA
}

Corresponding Author: Adrian Glodeanu, claudiug@ucm.es; Tel.: +34-633833061

\section{Word count: 3018}

\section{Abstract}

Spain has been one of the most affected regions by the COVID-19 worldwide, and Madrid its most affected city. In response to this, the Spanish government enacted a strict lockdown in late March, that was gradually eased until June. We explored differentials in mobility by area-level deprivation in the functional area of Madrid, before, during, and after the COVID-19 lockdown. We used cell phone-derived mobility indicators (\% of the population leaving their area) from the National Institute of Statistics (INE), and a composite measure of deprivation from the Spanish Society of Epidemiology (SEE). We computed changes in mobility with respect to pre-pandemic levels, and explored spatial patterns and associations with deprivation. We found that levels of mobility before COVID-19 were slightly higher in areas with lower deprivation. The economic hibernation period resulted in very strong declines in mobility, most acutely in low deprivation areas. These differences weakened during the re-opening, and levels of mobility were similar by deprivation once the lockdown was lifted. Given the existence of important socioeconomic differentials in COVID-19 exposure, it is key to ensure that these interventions do not widen existing social inequalities.

Keywords: COVID-19; coronavirus; mobility; commuting; quarantine; inequalities

\section{Introduction}

The novel coronavirus disease 2019 (COVID-19), caused by the severe acute respiratory syndrome coronavirus 2 (SARS-CoV-2), has disrupted societies worldwide to levels not seen since the 1918 influenza pandemic. There have been at least 34 million COVID-19 cases and at least one million deaths globally as of September 30, 2020 [1]. To mitigate its impact, an ensemble of non-pharmaceutical interventions has been put into place, disrupting economic and social activities worldwide [2]. One of these set of interventions, aimed at reducing contacts between individuals, includes physical distancing [3]. These interventions include minimizing inperson work, education, and entertainment, along with restrictions to regional and metropolitan mobility. These restrictions have had an enormous impact in the progression of the pandemic, saving thousands of lives in many different settings [4].

Spain has been one of the countries most affected by the pandemic, with 31.000 deaths and 748.000 cases between March and September 2020 [1]. Annual life expectancy during the first few months of the pandemic declined by 2 years in Madrid alone, while weekly life 
expectancy in Madrid and other regions of Spain declined by up to 10 years during the peak [5]. As part of the Spanish effort to mitigate the pandemic, lockdown measures were imposed due to the declaration of State of Alarm published on March 14, 2020 [6], along with the declaration of an "economic hibernation" on March 28, 2020. These efforts resulted in an $80 \%$ reduction in public transit use [7]. As part of the re-opening strategy (called "New normality"), mobility started increasing on May 25th, but has not reached pre-pandemic levels. For example, travel to transit, retail, supermarkets, parks, and workplaces has remained low for Madrid [8].

Given that the main purpose of these restrictions is to avoid exposure to SARS-CoV-2 in order to reduce the burden of infection, policies that increase mobility and forces workers to physically get to work, or that lift restrictions too early, may increase exposure for both individuals, that need to continue being mobile, and the entire population, that will continue having increased incidence [9]. One of these social processes limiting the effectiveness of these interventions is social inequality [10]. Specifically, significant sectors of the economy cannot work remotely, especially those in essential retail, health care, public safety, and transportation, along with janitorial and other manual workers. Most of these occupations are low-wage occupations with very little bargaining power, and are in many cases fulfilled by migrants and minorities [11].

To our knowledge, no previous study has systematically assessed changes in mobility by socioeconomic status during the lockdowns associated with COVID-19. To fill this gap, we propose to use data on small area-level socioeconomic status and daily mobility in small areas for the metropolitan area of Madrid, Spain, one of the most affected cities worldwide. Specifically, we propose to explore the changes in mobility patterns by area-level socioeconomic deprivation in the metropolitan area of Madrid during the lockdown and subsequent economic reopening. We hypothesize that geographic inequality patterns reported before COVID-19 are exacerbated as more disadvantaged areas had higher mobility during lockdown, and that this trend continued after the lifting of strict lockdown measures. As Spain currently undergoes a second wave of the pandemic, we believe this analysis can help inform future mobility restrictions to ensure health equity and better epidemic control.

\section{Methods}

Study setting

We use data on all 4341 census sections (called secciones censales in Spanish) and 310 mobility areas that compose the entire metropolitan area of Madrid, Spain. We define this area using the functional urban area definition, created by the Organisation for Economic Cooperation and Development [12]. Almost 6 million people live in the area, where intra-urban mobility is done by private motorized transport (37\%), public transit (35\%), and walking (28\%) [13]. Census sections are the smallest unit of aggregation of the Spanish census and house around 1500 people. Mobility areas are aggregations of 3.000 and 50.000 people [14], with an average of 19.120 inhabitants (SD=10737).

\section{Mobility}

We measured changes in mobility by small areas using data from the Spanish Statistical Office (INE) [14-15]. Mobility was quantified using cell phone location data, which has been 
shown to being more frequently and easily updatable data source to conventional travel surveys in mobility studies [16-18]. We used this data, aggregated to mobility areas, to compute five indicators of mobility outside of one's mobility area of residence in five different periods (Appendix table 1). These periods correspond to a pre-pandemic baseline, the economic hibernation period, and the three re-opening phases.

\section{Socioeconomic Deprivation Index}

We approximated area-level socioeconomic status using a socioeconomic deprivation index, a common strategy in health studies quantifying socioeconomic gradients [19-23]. Specifically, we used a socioeconomic deprivation index developed by the Spanish Epidemiology Society (Sociedad Española de Epidemiología, SEE) using data from the 2011 Spanish census. This index included seven census indicators selected through the use of principal component analysis. More details are available in [24], and on Appendix table 2. Since this index was available at the census section level, we aggregated the index to the mobility area level by averaging the value of each census section in each mobility area. We did this by conducting a spatial join of mobility areas and census sections, as a mobility area contains one or more census sections.

\section{Analysis}

The main objective of this analysis was to study socioeconomic differentials in mobility before, during, and after the lockdown in the metropolitan area of Madrid. We conducted this analysis in three steps. First, we explored the distribution of mobility, both over time through the five periods, and over space, by using choropleth maps. We also computed a summary indicator of changes, by subtracting the mobility in each lockdown period compared to the prepandemic week. Second, we examined the association between socioeconomic deprivation and mobility and changes in mobility by fitting a linear regression of mobility or changes in mobility as the dependent variable and socioeconomic deprivation as the independent variable. This study is based on bibliographic, statistical and cartographic data collected by Spanish Cadastre, Spanish National Institute of Geographic (IGN), Spanish Epidemiology Society (SEE) and Spanish Statistical Office (INE). Statistical analysis were conducted using R 3.6.2 [25]. Cartographical analysis were done in QGIS 3.2.3 [26].

Results

Table 1 shows a detailed description of the urban mobility patterns registered during the COVID-19 pandemic in the $\mathbf{3 1 0}$ mobility areas of the Madrid metropolitan area. In the prepandemic period, an average of $36 \%$ of the population left their mobility area daily. During the strictest lockdown, the economic hibernation period, this declined to $10 \%$, and increased slightly as the economy reopened, recovering to $17 \%, 19 \%$, and $20 \%$ in the first and second phases and during the complete reopening. Importantly, mobility was heterogeneous by area, with the $\%$ leaving their mobility area daily ranging from 18 to $61 \%$ in the pre-pandemic week, and from $3 \%$ to $16 \%$ in the economic hibernation period.

Figure 1 shows the change in mobility from the pre-pandemic week to the economic hibernation stage, the most restrictive lockdown, for all mobility areas of the metropolitan area of Madrid. We found a heterogeneous spatial pattern. First, mobility declined sharply in the 
central districts of Madrid, where most mobility areas had a decline of mobility of more than $80 \%$. Suburban areas were very heterogeneous, with some, especially in the North and West, having steep drops similar to the central parts of Madrid. On the other hand, the southern part of the city and suburban areas South of Madrid had the weakest drops in mobility, of less than $67 \%$.

Figure 2 shows the trends in changes in mobility during the four lockdown periods, compared to baseline, by levels of deprivation. First, we found that in the pre-pandemic period mobility was slightly lower in more deprived areas. However, we found that mobility was consistently higher in the same more deprived areas during all pandemic phases. We found a $78 \%$ decline in mobility during the economic hibernation period in the most deprived areas, compared to a $74 \%$ decline in the least deprived areas. This pattern persisted during the reopening phase, although differences between areas declined over time and were negligible in the last phase.

Figures 3 and 4 show the association between mobility and changes in mobility and deprivation. We found that, previous to the COVID-19 pandemic, a 1 SD increase in deprivation was associated with $0.79 \%$ lower mobility $(95 \% \mathrm{Cl}-1.55$ to -0.08$)$. This association was reverted during the lockdown, so that a 1 SD increase in deprivation was associated with $0.80 \%$ higher mobility ( $95 \% \mathrm{Cl}, 0.43$ to 0.98 ). During the re-opening, the association between deprivation and mobility strengthened, with a $1.48(95 \% \mathrm{Cl} 1.09$ to 1.88$)$ and $1.38 \%(95 \% \mathrm{Cl} 0.94$ to 1.81$)$ increase in mobility per 1 SD increase in deprivation during Phases 1 and 2, respectively. Last, during the full re-opening this association weakened again ( $\mathrm{B}=0.86,95 \% \mathrm{Cl} 0.34$ to 1.38$)$. We found that deprivation was associated with the changes in mobility with respect to the previous normality. Specifically, we found that a 1 SD increase in deprivation was associated with a $2.54 \%, 5.46 \%$, $5.26 \%$, and $3.78 \%$ weaker decline in mobility during the economic hibernation, phases 1 and 2 , and new normality, respectively.

Figure 5 shows the spatial co-occurrence of high/low levels of deprivation and stronger/weaker changes in average urban mobility levels during the economic hibernation period. We found areas of low deprivation and lower mobility in the central areas of the city and in the Northern and Western suburbs. We also found areas of high deprivation and high mobility in the southern areas of the city and suburbs. Appendix figures 1 and 2 show all quadrants of mobility and deprivation.

\section{Discussion}

In this study of urban mobility before, during, and after the lockdown due to COVID-19 in the metropolitan area of Madrid, we evidenced a heterogeneous mobility landscape that was strongly socially patterned. First, we found that mobility was very low during the economic hibernation period, with declines of up to $89 \%$ compared to baseline, and remained low during the reopening, with declines of up to $80 \%$, compared to baseline, in the last phase of reopening. Second, we found that this heterogeneity was spatially patterned, with the central parts of the city, and the northern and western suburbs, having the steepest drops in mobility. On the other hand, the southern parts of the city and southern suburbs had the weakest drops in mobility. This spatial pattern follows the same pattern as deprivation, that we found to be very predictive of changes in mobility, so that more deprived areas experienced a weaker drop in mobility. This 
social pattern was especially marked during Phases 1 and 2 of the re-opening, as compared to the strictest lockdown and the full re-opening.

The Center-North-West vs South and Southeast pattern we found represents the usual segregation pattern of the city of Madrid. Specifically, Madrid has been, since after the 19th century, characterized by a spatial border between the rich north and the poor south that, during the last century has been consolidated as a northeast - southeast one [27-28]. This generalization is important to understand the factors behind the results in this manuscript, as the ring road $\mathrm{M} 30$ and the $\mathrm{A} 2$ highway (in the Northeast) creates the main border between the more vulnerable neighborhoods in the South, versus the rest of the central part of the city. The segregation of Madrid has been exacerbated following the 2008 recession [29].

In the baseline week, named Previous Normality here, we observed a pattern of higher mobility in less deprived areas. However, during the strictest part of the lockdown this pattern was reversed, with higher mobility in more deprived areas. During this part, only people working in essential services were allowed to even leave their home for work purposes, while everyone else was restricted to teleworking or not working at all. Since essential workers from sectors such as healthcare, grocery, manufacturing, transportation or public safety have to continue working in-person, with limited accommodations, people working in these sectors will continue being exposed. Essential workers are vital to the well-being and survival of the population during the pandemic, but, at the same time, they are highly vulnerable to the economic and health risks posed by the pandemic [30]. Specifically, low wage workers are two or three times more likely than high wage workers to not having access to safety measures that prevent the transmission of COVID-19 (masks, hand sanitizer, training and so on) [31]. In fact, $65 \%$ were unable to practice social distancing, which may be easier for high wage workers who can do teleworking easily. This leads to the idea reported elsewhere that social distancing it is a privilege [32-33].

As lockdown measures were progressively lifted, these patterns worsened, and the social patterning of mobility strengthened. In phases 1 and 2, the main difference in terms of working and social distancing conditions changed from the dichotomy between essential and non-essential workers to commuters and teleworkers. People who could telework were able to stay at home, reducing exposure to COVID-19, while people who work in places that need inperson work continued being more exposed. The differences we observed in mobility by deprivation are most likely a reflection of the social class of workers that can or cannot telework. According to a report from the Spanish National Bank, teleworking is far more common among people with permanent jobs as compared to temporal workers, with $34 \%$ of workers in permanent jobs teleworking for more than half of their work days, as compared to $10 \%$ for temporal workers [35]. Apart from the working conditions and lack of telecommuting opportunities, other inequalities are underlying the COVID-19 pandemic, such as food insecurity, unstable housing, or domestic violence [32]. However, there is a limited number of studies that analyze the intersection of socioeconomic conditions and the vulnerability that it is introduced by inequalities [36-37]. There are even fewer that, spatially, describe the differences in essential commuting during the lockdown period or the peak of the pandemic [38-39], even though wealth inequality has been studied as a health determinant in the literature [40-42].

Our results are similar to those reported in other settings. Therese, K. et al. [32] found a socioeconomic and racial component in subway travelling while the pandemic; areas with the 
lower median income, a greater percentage of individuals who identify as non-white and/or Hispanic/Latino, a greater percentage of essential workers, and a greater percentage of healthcare workers had more subway use during the pandemic. Ayyub, 2020 [33] sheds a light on the second component of the vulnerability imposed by COVID-19; there are people for whom staying home means a drop in their income and familiar wage problems. This is especially important for the informal economy, and some sectors such as construction and agriculture that rely on in-person labor. It is estimated that around 2 to 4 million people in Spain have entered poverty during the lockdown [34] due to working in the informal economy.

Our study has several limitations. First, our baseline mobility data was limited to November 2019, in a different season, meaning that mobility patterns may have changed beyond the role of the lockdown. Second, we lacked a mobility estimate for the complete reopening phase, and relied on the week before that re-opening fully took place. This does not allow us to estimate the heterogeneity and social patterning of mobility during the actual reopening. Our deprivation index was calculated using data from the 2011 census, and there may be a degree of misclassification. However, as shown in previous studies, inequalities in Madrid continue increasing [43], and segregation continues intensifying [44], so our results represent a conservative estimation of these inequalities. Finally, the modifiable areal unit problem (MAUP) could have been a problem of this project's methodology as it introduces statistical bias that can impact the results. Nevertheless, the mobility areas were created to counteract this possible phenomenon.

As Spain entered a second COVID-19 wave with large outbreaks in Madrid in September 2020, the regional government of Madrid started a series of neighborhood-level lockdowns that prohibited non-work-related mobility. However, these lockdowns still forced workers that cannot telework to be physically present at their job locations, frequently outside their residential neighborhood. Our results show that these types of policies may have negative impacts on poorer neighborhoods, as their residents are more likely to have to work in person.

\section{References}

1 Johns Hopkins Coronavirus Resource Center. COVID-19 Dashboard by the Center for Systems Science and Engineering (CSSE). Web: https://coronavirus.jhu.edu/map.html

2 Buchanan, L. "54 Ways Coronavirus Has Changed Our World". The New York Times. May 27, 2020. Available online: https://www.nytimes.com/interactive/2020/05/27/sunday-review/coronaviruseffects.html (Accessed on July 16, 2020).

3 Centers for Disease Control and Prevention. "Social Distancing. Keep a Safe Distance to Slow the Spred". Available online: https://www.cdc.gov/coronavirus/2019-ncov/prevent-getting-sick/social-distancing.html (Accesed on July 20, 2020).

4 Flaxman, S.; Mishra, S.; Gandy, A. et al. "Estimating the effects of non-pharmaceutical interventions on COVID-19 in Europe". Nature. 2020. 584, pp. 257-261 . Available online: https://doi.org/10.1038/s41586020-2405-7 (Accessed on July 24, 2020).

5 Trias-Llimós, S.; Riffe, T.; Bilal, U. "Monitoring life expectancy levels during the COVID-19 pandemic: Example of the unequal impact in Spanish regions". MedRXiv. 2020 (Pre-print). Available online: https://www.medrxiv.org/content/10.1101/2020.06.03.20120972v2.full.pdf (Accessed on September 9, 2020) 
6 Spain. Real Decreto 463/2020, de 14 de marzo, por el que se declara el estado de alarma para la gestión de la situación de crisis sanitaria ocasionada por el COVID-19, núm. 3692, p. 25392. Web: https://www.boe.es/eli/es/rd/2020/03/14/463/dof/spa/pdf

7 Moovit. Impact of Coronavirus (COVID-19) on Public Transit Usage. 2020. Available online: 20, 2020).

2588 Google. COVID-19 Community Mobility Reports. 2020. Available online:

259 https://www.gstatic.com/covid19/mobility/2020-07-17 ES Mobility Report es.pdf (Accessed on July 22, 260 2020).

2619 Han, E.; Mei Jin Tan, M.; Turk, E. et al. "Lessons learnt from easing COVID-19 restrictions: an analysis of countries and regions in Asia Pacific and Europe". The Lancet. 2020. Available online:

263 https://www.thelancet.com/journals/lancet/article/PIIS0140-6736(20)32007-9/fulltext (Accessed on 264 October 13, 2020).

26510 Bambra, C.; Riordan, R.; Ford, J.; Matthews, F. "The COVID-19 pandemic and health inequalities". Journal of Epidemiology and Community Health. 2020. 74 (11). Available online: https://jech.bmj.com/content/74/11/964 (Accessed on September 2020).

26811 Shadmi, E.; Chen, Y.; Dourado I. et al. "Health Equity and COVID-19: global perspectives". International 269 Journal for Equity in Health. 2020. 19 (104), pp. 1-16. Available online:

270 https://ink.springer.com/content/pdf/10.1186/s12939-020-01218-z.pdf (Accessed on September 9, 271 2020).

27212 Organisation for Economic Co-operation and Development (OECD). Functional urban areas in Spain.

273 2019. Available online: http://www.oecd.org/cfe/regionaldevelopment/Spain.pdf (Accessed on July, 274 2020).

27513 Comunidad de Madrid. Encuesta sintética de movilidad en la Comunidad de Madrid-ESM14.

276 December, 2014. Available online: https://www.crtm.es/media/519661/esm 2014.pdf (Accessed on July $27720,2020)$.

27814 Instituto Nacional de Estadística (Spanish Statistical Office-SSO). Análisis de la movilidad de la 279 población durante el estado de alarma por COVID-19 a partir de la posición de los teléfonos móviles.

280 Metodología. 2020. Available online: https://www.ine.es/covid/exp movilidad covid proyecto.pdf

281 (Accessed on July 29, 2020).

28215 Instituto Nacional de Estadística (Spanish Statistical Office-SSO). Evolución de la movilidad por ámbito 283 geográfico durante el estado de alarma por COVID-19. 2020. Available online:

284 https://www.ine.es/covid/covid movilidad.htm\#tablas resultados (Accessed on July, 2020).

28516 Nyhan, M.; Grauwin, S.; Britter, R.; Misstear, B.; McNabola, A.; Laden, F.; Barrett, S.R.H.; Ratti, C.

286 "Exposure Track" The Impact of Mobile-Device-Based Mobility Patterns on Quantifying Population

287 Exposure to Air Pollution". Environmental Science and Technology. 2016. 50, pp. 9671-9681. Available

288 online: https://pubs.acs.org/doi/pdf/10.1021/acs.est.6b02385 (Accessed on July 31, 2020).

28917 Calabrese, F.; Colonna, M.; Lovisolo, T.; Parata, D. "Real-Time Urban Monitoring Using Cell Phones: A

290 Case Study in Rome". IEE Transactions on intelligent transportation systems. 2011. 12 (1), pp. 141-151.

291 Available online: http://hdl.handle.net/1721.1/101712 (Accessed on July 31, 2020).

29218 Calabrese, F.; Diao, M.; Di Lorenzo, G.; Jr, J.F.; Ratti, C. "Understanding individual mobility patterns

293 from urban sensing data: a mobile phone trace example". Transportation Research Part C: Emerging 
19 Tello, J.E.; Jones, J.; Bonizzato, P.; Mazzi, M.; Amaddeo, F. "A census-based socio-economic status (SES) index as a tool to examine the relationship between mental health services use and deprivation". Social Science and Medicine. 2005. 61(10), pp. 2096-2105. Available online:

299 https://doi.org/10.1016/j.socscimed.2005.04.018 (Accessed on August 3, 2020).

30020 Bell, N.; Hayes, M.V. "The Vancouver Area Neighbourhood Deprivation Index (VANDIX): A Census-

301 based Tool for Assessing Small-area Variations in Health Status". Canadian Journal of Public Health. 2012.

302 103(2), pp.28-32. Available online: https://www.jstor.org/stable/41995686 (Accessed on August 3, 2020).

30321 Deonandan, R.; Campbell, K.; Ostbye, T.; Tummon, I.; Robertson, J. "A Comparison of Methods for

304 Measuring Socio-economic Status by Occupation or Postal Area". Chronic diseases in Canada. 2000. 21(3), 305 pp.114-118. Available online: https://pubmed.ncbi.nlm.nih.gov/11082347/ (Accessed on August 3, 2020).

30622 Walker, A.E.; Becker, N.G. "Health inequalities across socio-economic groups: comparing geographic-

307 area-based and individual-based indicators". Public Health. 2005. 119(12), pp.1097-1104. Available

308 online: https://doi.org/10.1016/j.puhe.2005.02.008 (Accessed on August 3, 2020).

30923 Bell, N.; Schuurman, N.; Hayes, M.V. "Using GIS-based methods of multicriteria analysis to construct 310 socio-economic deprivation indices". International Journal Of Health Geographics. 2007. 6(17). Available 311 online: https://link.springer.com/article/10.1186/1476-072X-6-17\#citeas (Accessed on August 3, 2020).

31224 Sociedad Española de Epidemiología (Spanish Epidemiology Society). Índice de Privación 2011 de la

313 Sociedad Española de Epidemiología; Manual de Uso. 2011. Available online:

314 https://www.sciencedirect.com/science/article/pii/S0213911119302729

31525 R Core Team. "R: A language and environment for statistical computing". R Foundation for Statistical 316 Computing. 2020. Vienna, Austria. Available online: https://www.R-project.org/.

31726 QGIS Development Team. "QGIS Geographic Information System". Open Source Geospatial Foundation 318 Project. 2020. Available online: http://qgis.osgeo.org

31927 Pontes, J. "Madrid a dos velocidades: Sureste metropolitano vs noroeste residencial". El Confidencial.

320 2020. Article in press: https://www.nuevatribuna.es/articulo/actualidad/estudio-sociologico-desigualdad-

321 comunidadmadrid-sureste-noreste/20200505081326174443.html (Accessed on August 20, 2020).

32228 Guillén, B. "La brecha entre ricos y pobres en Madrid, la más grande de Europa”. El País. 2015. Article 323 in press: https://elpais.com/ccaa/2015/10/09/madrid/1444416065 033414.html (Accesed on August 20, 324 2020).

32529 Rubiales Pérez, M. "Territorio y crisis: impacto territorial de la crisis económica en las regiones

326 metropolitanas de Madrid y Barcelona". Scripta Nova. 2016. 20. Available online:

327 https://doi.org/10.1344/sn2016.20.17208 (Accessed on September 29, 2020).

32830 Schneider, D.; Harknett, K. Essential and Vulnerable: Service-Sector Workers and Paid Sick Leave. SHIFT 329 Report. 2020. Available online:

330 https://shift.hks.harvard.edu/files/2020/04/Essential and Vulnerable Service Sector Workers and Pai 331 d Sick Leave.pdf (Accessed on July 19, 2020).

332 31. Hammonds, C; Kerrissey, J. "We are not heroes because it is not a choice", A Survey of Essential 333 Workers' Safety and Security During COVID-19. Umass Amherst Labor Center. 2020. Available online: 334 https://www.umass.edu/Irrc/sites/default/files/Western\%20Mass\%20Essential\%20Worker\%20Survey\%2 335 0-\%20May\%202020.pdf (Accessed on July 19, 2020). 

Preprint. Available online: https://doi.org/10.1101/2020.05.28.20115949 (Accessed on July 21, 2020).

34034 Sánchez, C. El virus deja sin ingresos a 2 millones de trabajadores que operan en negro. El

341 Confidencial. April, 2020. Available online: https://www.elconfidencial.com/economia/2020-04-

342 05/economia-sumergida-coronavirus-pandemia-negro-hosteleria 2534287/ (Accessed on July 24, 2020).

34335 Banco de España. El teletrabajo en España. Boletín económico del Banco de España. 2020. Available

344 online: https://www.bde.es/bde/es/secciones/informes/boletines/articulos-analit/ (Accessed on July 21, 345 2020).

34636 M. Blow, C. Social distancing is a privilege. The New York Times. April 5, 2020. Available online:

347 https://www.nytimes.com/2020/04/05/opinion/coronavirus-social-distancing.html (Accessed on July 21,

348 2020).

34937 Mikolai, J.; Keenan, K.; Kulu, H. Intersecting household level health and socio-economic vulnerabilities 350 and the COVID-19 crisis: An analysis from the UK. SSM-Population Health. Journal pre-proof. 2020.

351 Available online: https://doi.org/10.1016/j.ssmph.2020.100628 (Accessed on July 22, 2020).

352

353

354

355

356

357

358

359

360

361

362

363

364

365

366

367

368

369

370

371

372

373

374

375

376

377 38 Klein, B.; LaRock, T.; McCabe, S.; Torres, L.; Privitera, F.; Lake, B.; U.G. Kraemer, M.; S. Brownstein, J.; Lazer, D.; Eliassi-Rad, T.; V. Scarpino, S.; Chinazzi, M.; Vespignani, A. Assessing changes in commuting and individual mobility in major metropolitan areas in the United States during the COVID-19 outbreak. Northeastern University, Network Science Institute. March 31, 2020. Available online: https://www.networkscienceinstitute.org/publications/assessing-changes-in-commuting-and-individualmobility-in-major-metropolitan-areas-in-the-united-states-during-the-covid-19-outbreak

39 Quealy, K. The richest neighbourhoods emptied out most as coronavirus hit New York City. The New York Times. May 15, 2020. Available online: https://www.nytimes.com/interactive/2020/05/15/upshot/who-left-new-york-coronavirus.html (Accessed on July 22, 2020).

40 Ezzati, M.; Friedman, A.B.; Kilkarni, S.C.; Murray, C.J.L. The Reversal of Fortunes: Trends in County Mortality and Cross-County Mortality Disparities in the United States. PLOS Medicine, 5(5): e119. 2008. Available online: https://doi.org/10.1371/journal.pmed.0050066 (Accessed on July 23, 2020).

41 Pickett, K.E.; Wilkinson, R.G. Income inequality and health: a causal review. Social Science \& Medicine. 2015. 128, pp. 316-26. Available online: https://doi.org/10.1016/j.socscimed.2014.12.031 (Accessed on July 23, 2020).

42 Krisberg, K. Income inequality: when wealth determines health: earnings influential as lifelong social determinant of health. The Nations Health 2016. 46 (8), pp. 1-17. Available online:

http://thenationshealth.aphapublications.org/content/46/8/1.1

43 Fundación FOESSA. "Informe sobre exclusión y desarrollo social en Madrid. Resultados de la Encuesta sobre Integración y Necesidades Sociales 2018”. 2019. Available online: https://caritasweb.s3.amazonaws.com/main-files/uploads/sites/16/2019/10/MADRID-VIII-Informe-FOESSA.pdf (Accessed on September 29, 2020).

44 Picardo Costales, L. "Dime dónde vives pero no sabré quién eres. Nuevas dinámicas en la distribución socio-espacial. El caso de Madrid entre 2001 y 2011". 2018. N13, pp. 79-100. Available online: 10.20868/tf.2018.13.3805 (Accessed on September 30, 2020). 
45 Spain. Real Decreto-ley 10/2020, de 29 de marzo, por el que se regula un permiso retribuido

379 recuperable para las personas trabajadoras por cuenta ajena que no presten servicios esenciales, con el

380 fin de reducir la movilidad de la población en el contexto de la lucha contra el COVID-19, núm. 87, p.

381 27629. Web: https://www.boe.es/boe/dias/2020/03/29/pdfs/BOE-A-2020-4166.pdf

38246 Spain. Orden SND/399/2020, de 9 de mayo, para la flexibilización de determinadas restricciones de ámbito nacional, establecidas tras la declaración del estado de alarma en aplicación de la fase 1 del Plan para la transición hacia una nueva normalidad, núm. 130, sec. I, p. 31998. Web:

47 Spain. Orden SND/414/2020, de 16 de mayo, para la flexibilización de determinadas restricciones de ámbito nacional, establecidas tras la declaración del estado de alarma en aplicación de la fase 2 del Plan para la transición hacia una nueva normalidad, núm. 138, sec. I, p. 33312. Web: https://www.boe.es/boe/dias/2020/05/16/pdfs/BOE-A-2020-5088.pdf 48 Spain. Real Decreto-ley, de 9 de junio, de medidas urgentes de prevención, contención y coordinación para hacer frente a la crisis sanitaria ocasionada por el COVID-19, núm. 163, sec. I, p. 38723. Web: https://www.boe.es/boe/dias/2020/06/10/pdfs/BOE-A-2020-5895.pdf

\section{Acknowledgements}

394 We want to acknowledge the Instituto Nacional de Estadística (INE) and the Sociedad Española de Epidemiología (SES) for making their mobility and deprivation data publicly available.

Funding

397

398

399

400

401

402

403

404

405

406

407

408

409

410

411

UB was supported by the Office of the Director of the National Institutes of Health under award number DP5OD26429. PG was supported by the European Union's Horizon 2020 research and innovation programme under the Marie Skłodowska-Curie grant agreement No 842957. The funding sources had no role in the analysis, writing or decision to submit the manuscript.

\section{Conflicts of interest}

The authors declare no conflict of interest.

(1)

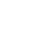

6


414 Tables and figures

415 Table

416 Table 1: mobility and changes in mobility by phase and deprivation

\begin{tabular}{|c|c|c|c|c|c|}
\hline & \multicolumn{5}{|c|}{ \% people going outside their residential area } \\
\hline & Previous N. & Economic $\mathrm{H}$. & Phase 1 & Phase 2 & New Normality \\
\hline Less deprived & 37,59 & 8,14 & 15,86 & 17,46 & 19,33 \\
\hline Moderately deprived & 36,15 & 8,83 & 17,66 & 19,01 & 19,94 \\
\hline \multirow[t]{3}{*}{ More deprived } & 35,12 & 9,16 & 18,00 & 19,34 & 19,86 \\
\hline & \multicolumn{5}{|c|}{ Relative Change in \% people going outside their residential area compared to Previous Normality } \\
\hline & Previous N. & Economic $\mathrm{H}$. & Phase 1 & Phase 2 & New Normality \\
\hline Less deprived & Reference & -78.35 & -57.81 & -53.55 & -48.58 \\
\hline Moderately deprived & Reference & -75.57 & -51.15 & -47.41 & -44.84 \\
\hline \multirow[t]{3}{*}{ More deprived } & Reference & -73.92 & -48.75 & -44.93 & -43.45 \\
\hline & \multicolumn{5}{|c|}{ Relative Change in \% people going outside their residential area compared to previous phase } \\
\hline & Previous N. & Economic $\mathrm{H}$. & Phase 1 & Phase 2 & New Normality \\
\hline Less deprived & & $-78,35$ & 94,88 & 10,1 & 10,73 \\
\hline Moderately deprived & & $-75,57$ & 100,02 & 7,61 & 4,92 \\
\hline More deprived & & $-73,92$ & 96,51 & 7,46 & 2,69 \\
\hline
\end{tabular}

417

Footnote: relative changes are calculated as 100*(Mobility in new period-mobility in baseline period)/mobility in baseline period

418

419

420

421

422

423

424

425

426

427

428

429

430 
Figure 1: changes in mobility comparing previous normality to the economic hibernation period (lockdown)

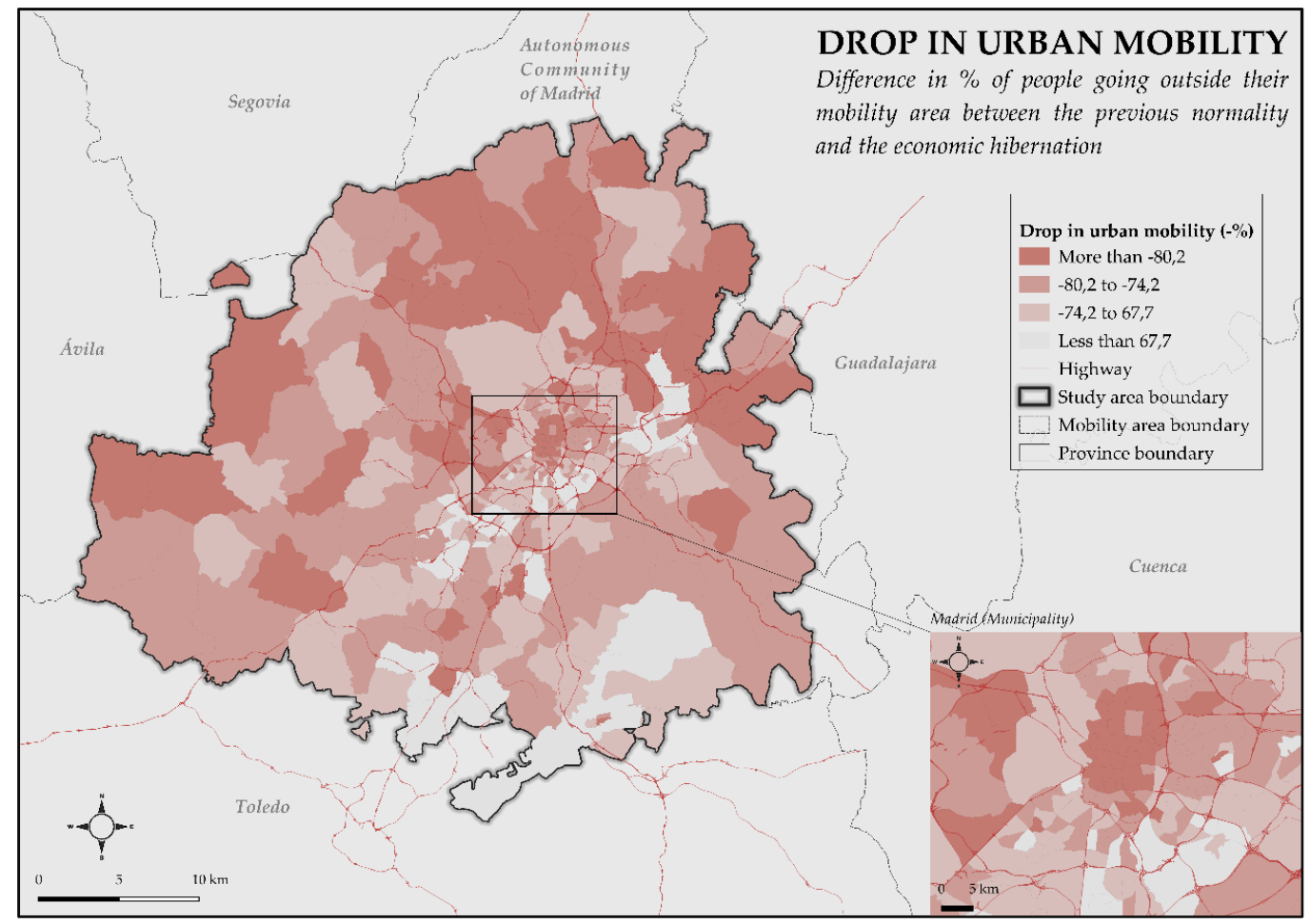

Figure 2: mobility by phase and deprivation during the COVID-19 lockdown and re-opening in Madrid

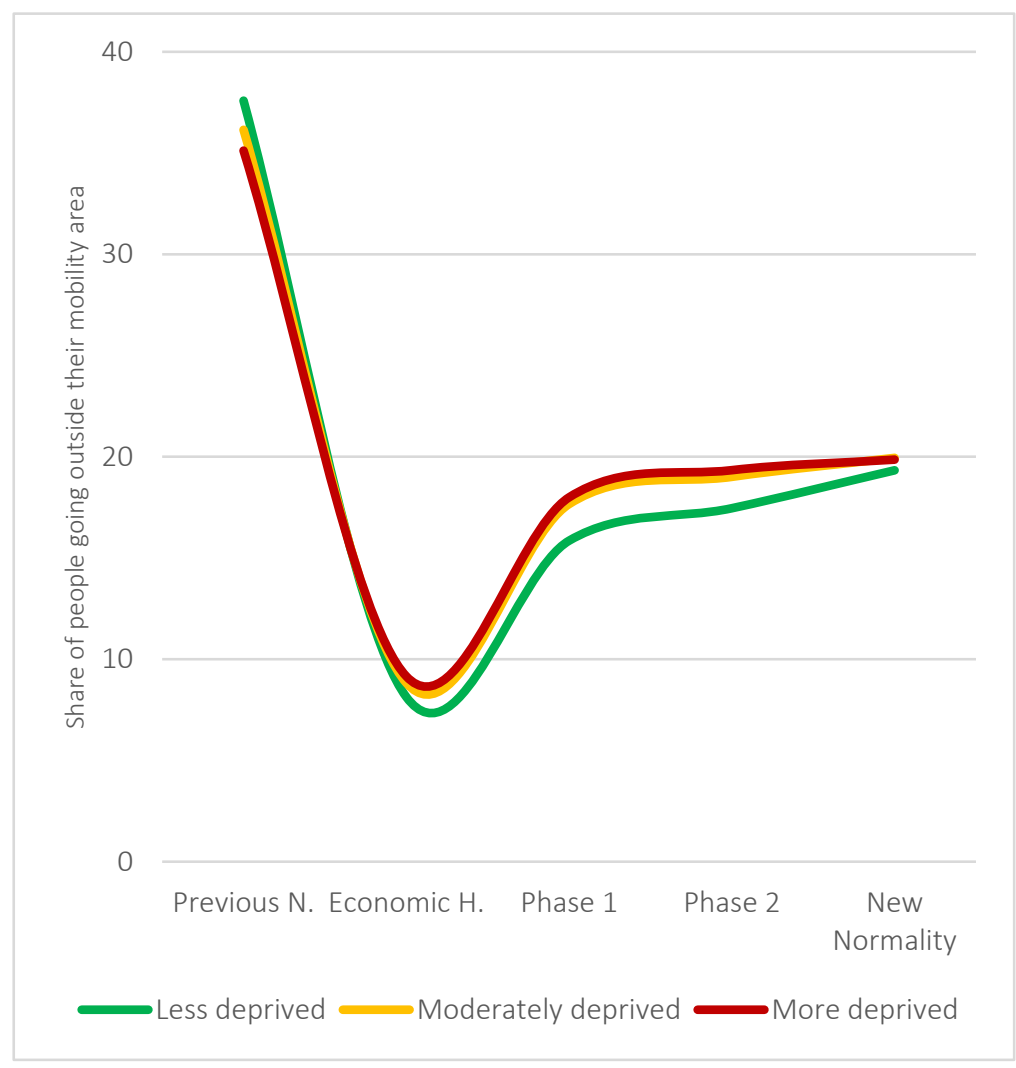


Figure 3: mobility and deprivation during the five periods of this study in Madrid

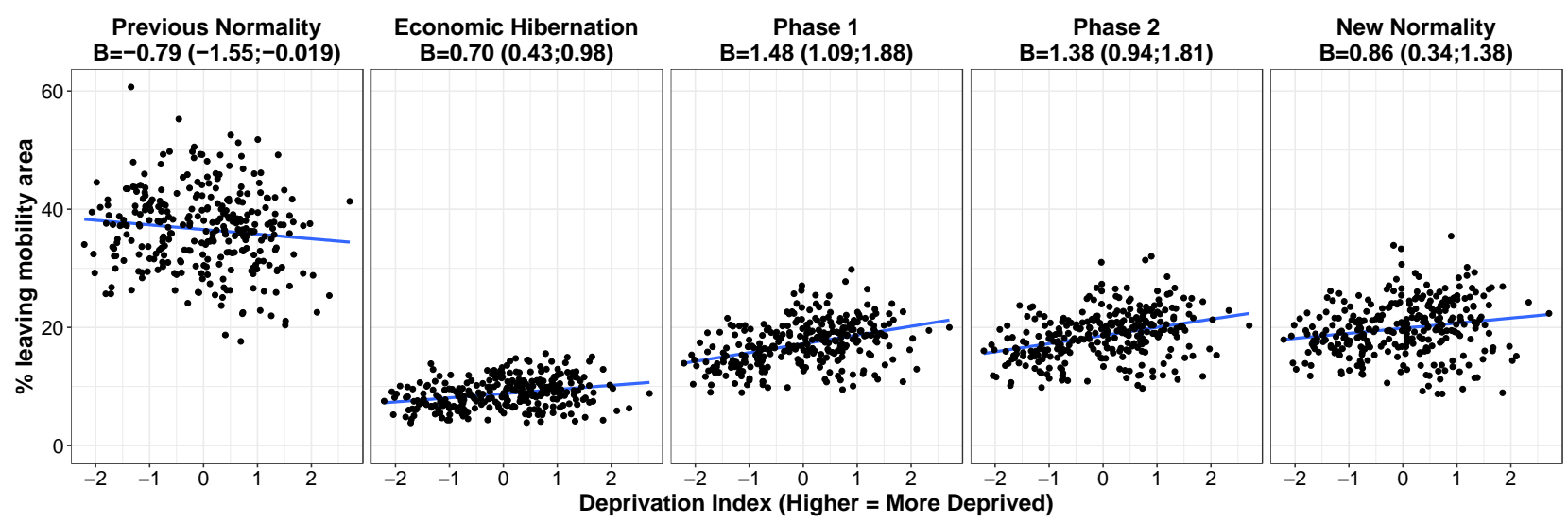

Figure 4: changes in mobility compared to previous normality and deprivation in Madrid

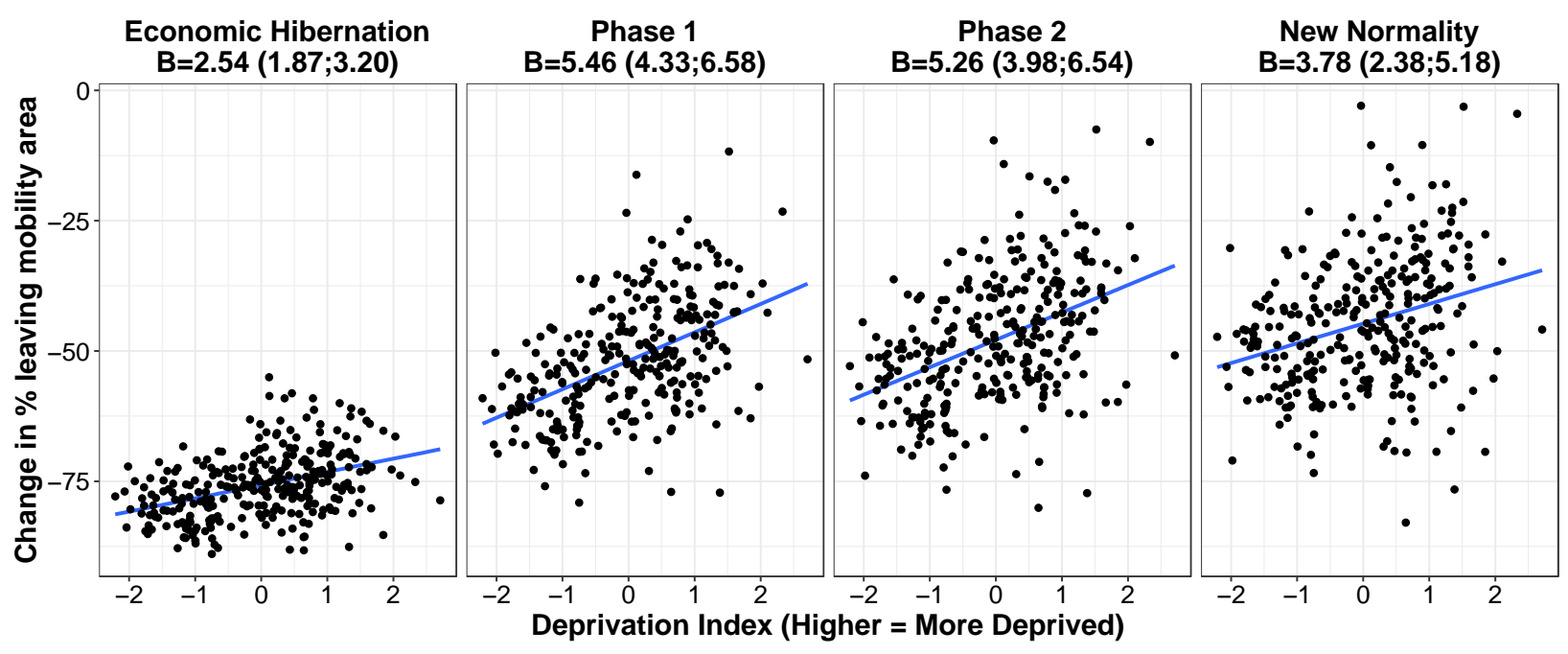

453 
Figure 5: localization of mobility areas with spatial co-occurrence of deprivation and mobility in

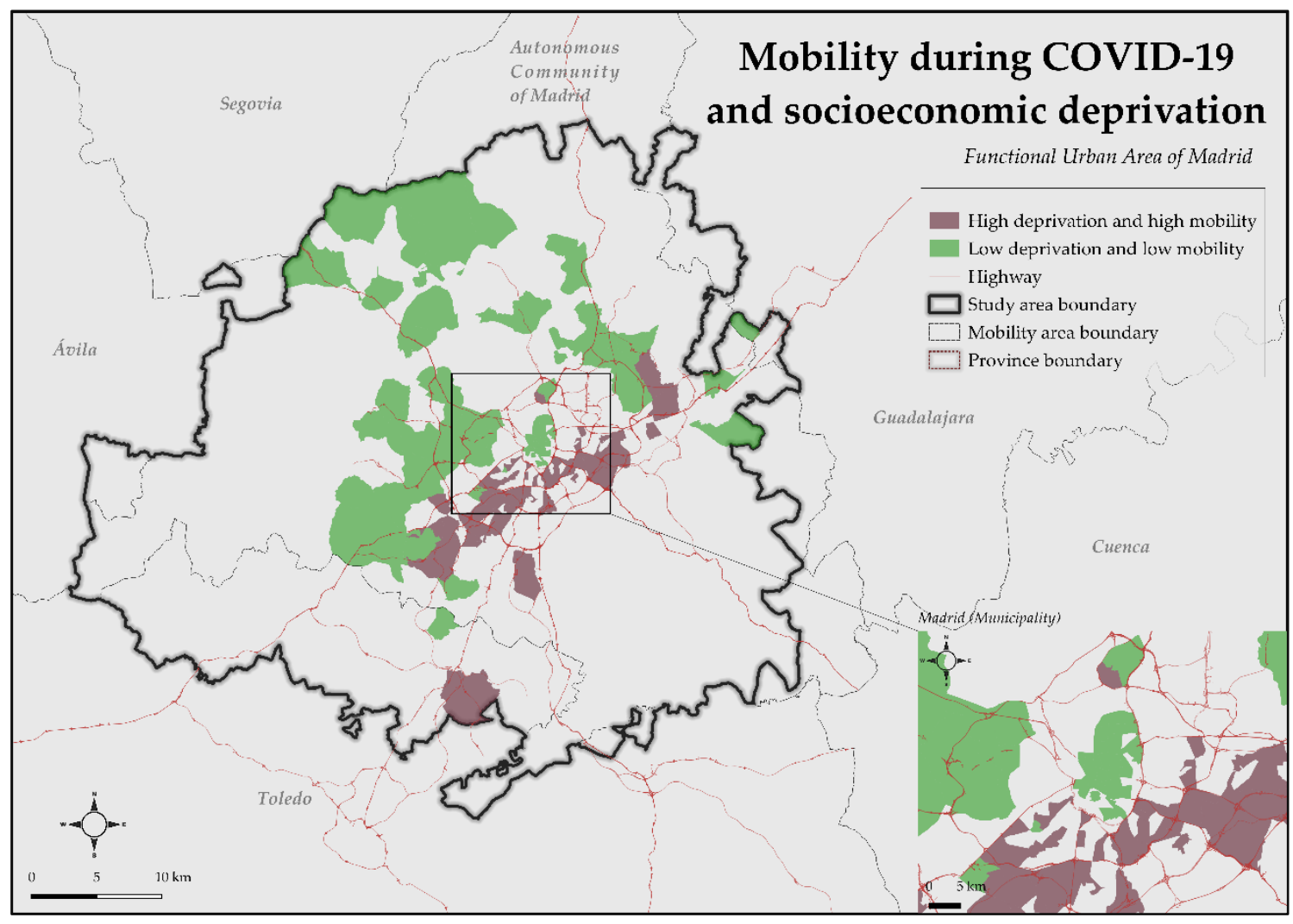

